\title{
Impacts of Ground Slope on Main Performance Figures of Solar Chimney Power Plants: A Comprehensive CFD Research with Experimental Validation
}

\author{
Erdem Cuce $\mathbb{D}^{1,2}$ Pinar Mert Cuce $\mathbb{D}^{2,3}$ Harun Sen $\mathbb{D}^{1,2}$ K. Sudhakar $\mathbb{D}^{4,5,6}$ \\ Umberto Berardi $\left(1,{ }^{7}\right.$ and Ugur Serencam $\mathbb{1}^{8}$ \\ ${ }^{1}$ Department of Mechanical Engineering, Faculty of Engineering and Architecture, Recep Tayyip Erdogan University, \\ Zihni Derin Campus, 53100 Rize, Turkey \\ ${ }^{2}$ Low/Zero Carbon Energy Technologies Laboratory, Faculty of Engineering and Architecture, Recep Tayyip Erdogan University, \\ Zihni Derin Campus, 53100 Rize, Turkey \\ ${ }^{3}$ Department of Energy Systems Engineering, Faculty of Engineering and Architecture, Recep Tayyip Erdogan University, \\ Zihni Derin Campus, 53100 Rize, Turkey \\ ${ }^{4}$ Faculty of Mechanical and Automobile Engineering Technology, Universiti Malaysia Pahang, 26600, Malaysia \\ ${ }^{5}$ Energy Centre, Maulana Azad National Institute of Technology Bhopal, India \\ ${ }^{6}$ Department of Electric stations, Grids and Power Supply Systems, South Ural State University, Chelyabinsk, \\ Russian Federation, India \\ ${ }^{7}$ Department of Architectural Science, Ryerson University, Toronto, ON, Canada M5B $2 \mathrm{~K}$ \\ ${ }^{8}$ Department of Civil Engineering, Faculty of Engineering Marmara University, 34722 Istanbul, Turkey
}

Correspondence should be addressed to Erdem Cuce; erdemcuce@gmail.com

Received 8 November 2020; Revised 8 May 2021; Accepted 14 May 2021; Published 24 May 2021

Academic Editor: Alberto Álvarez-Gallegos

Copyright (C) 2021 Erdem Cuce et al. This is an open access article distributed under the Creative Commons Attribution License, which permits unrestricted use, distribution, and reproduction in any medium, provided the original work is properly cited.

\begin{abstract}
Geometric parameters in solar chimney power plants are numerically optimised for the purpose of better power output figures. Several parameters have been investigated in the pilot plant such as chimney height and diameter, collector diameter and slope, and slenderness. However, ground slope has not been studied to date despite its perspicuous impact on turbulent flow. In this study, the impacts of the different slope angles of the ground, where the solar radiation is absorbed through the collector, on the main performance parameters of the system are numerically analysed through a reliable CFD software ANSYS FLUENT. By considering the actual geometric figures of the pilot plant, a 3D model is constructed through DO (discrete ordinates) solar ray tracing algorithm and RNG k- $\varepsilon$ turbulence model. For the solar intensity of $1000 \mathrm{~W} / \mathrm{m}^{2}$, the maximum velocity inside the system is found to be $14.2 \mathrm{~m} / \mathrm{s}$, which is in good accordance with the experimental data of $15.0 \mathrm{~m} / \mathrm{s}$. Starting from $5 \mathrm{~m}$ inside the collector, the chimney inlet heights are reconfigured $0.209,0.419,0.625,0.838$, and $1.04 \mathrm{~m}$, respectively, and when the ground slope is $0.1,0.2,0.3,0.4$, and $0.5^{\circ}$, the changes in the performance output of the system are investigated. For the reference case which refers to the horizontal ground, the maximum air velocity is determined to be $14.2 \mathrm{~m} / \mathrm{s}$ and the power output is $54.3 \mathrm{~kW}$. However, when the ground slope is made $0.5^{\circ}$, it is observed that the maximum velocity increases by $37 \%$ to $19.51 \mathrm{~m} / \mathrm{s}$, and the power output is enhanced to $63.95 \mathrm{~kW}$ with a rise of $17.7 \%$. Sloping ground is found a key solution to improve the turbulent effects inside the plant, thus to enhance the electrical power output.
\end{abstract}

\section{Introduction}

The dramatic rise in energy consumption figures is inevitable in today's world with outstanding technological develop- ments and notably increasing human population. The increase in energy use has led to more discussion of $\mathrm{CO}_{2}$ emissions and environmental pollution than ever before, especially because of the higher consumption of primary 
energy resources. Increasing tendency to renewable energy sources for energy production has become a joint work of researchers in recent years. Considering the diversity of renewable energy sources as well as their efficiency and accessibility, it can be easily asserted that the sun is in the most popular position. Although the use of solar energy goes back to ancient times, its use for electricity generation has become widespread in recent years. Solar chimney power plants attracted the attention of researchers with the first prototype, Manzanares, in the late 1900s. Although not physically complex, the system consists of three main structural elements such as collector, chimney, and turbine [1]. The collector directly exposed to the solar radiation creates a dynamic system air at the bottom and provides the transmission of the solar radiation it receives to the ground. The temperature of the air in the dynamic system increases with the solar radiation passing through the collector. Solar radiation reaching the ground causes an increase in temperature here and thus heat transfer takes place from the ground to the system air. This heat transfer yields to an increase in the temperature of the system air as a consequence of the developed upward movement. The system air starting to move upwards is pulled up from the chimney by the vacuum effect at the chimney inlet. The chimney creates a pressure difference due to its height [2]. In the meantime, the kinetic energy of the system air is converted into electrical energy with the turbine at a certain height. In the experiments with the first prototype, $55 \mathrm{~kW}$ power output and $15 \mathrm{~m} / \mathrm{s}$ maximum air velocity are determined [3]. With the experimental data obtained from the first prototype, numerous theoretical and mathematical models on solar chimney power plants are produced. When the studies are examined, it is seen that the researchers analyse the performance parameters of the system in different climatic, environmental, and operational conditions. Dhahri et al. [4] report that the change in radiation intensity affects the airflow rate and temperature increase in the system, and the air velocity, which is $8.8 \mathrm{~m} / \mathrm{s}$ at $300 \mathrm{~W} / \mathrm{m}^{2}$, increases by $50 \%$ at $900 \mathrm{~W} / \mathrm{m}^{2}$ and rises to $13.8 \mathrm{~m} / \mathrm{s}$. Similarly, Esfinadi et al. [5] verify that the solar intensity increases the airflow rate in the system. Abdelmohimen and Algarni [6] state that any increase in radiation intensity yields to an increase in the airflow rate and the power output of the system. They claim that the system with $400 \mathrm{~W} / \mathrm{m}^{2}$ radiation intensity gives a maximum air velocity of $6 \mathrm{~m} / \mathrm{s}$ and a power output of $25 \mathrm{~kW}$. When the radiation intensity is $800 \mathrm{~W} / \mathrm{m}^{2}$, the airflow rate is enhanced by about $30 \%$ and the power output rises by $88 \%$ to $47 \mathrm{~kW}$.

Solar chimney power plants are significantly affected by environmental factors. Initial temperature and solar radiation intensity are the most important environmental parameters affecting the power output of the system. Other parameters that affect the system performance are geometric and design parameters. Environmental effects cannot be predicted precisely, but the effect of geometric parameters can be analysed in advance with theoretical and numerical studies. It is clear that increasing the collector radius will increase the performance of solar chimney power plants as it will allow the solar radiation to penetrate a greater area. Referring to the Manzanares pilot plant, researchers argue that changing the collector radius affects the power output and efficiency of the system. Li et al. [7] claim that the Manzanares pilot plant will give $53.5 \mathrm{~kW}$ power output at $122 \mathrm{~m}$ collector radius, and when the collector radius is made $244 \mathrm{~m}$, the power output will increase by $120 \%$ to approximately $118 \mathrm{~kW}$, but the power output of the system will not increase after $500 \mathrm{~m}$ collector radius. Esfinadi et al. [5] argue that increasing the collector radius of the Manzanares pilot plant will increase the power output of the system while reducing its efficiency. Increasing the height of the chimney in solar chimney power plants has a positive effect on the power output by increasing the flow rate of the system air at the chimney inlet [8]. Researchers state that increasing the chimney height of the Manzanares pilot plant will increase its power output and efficiency [9]. The effect of geometric parameters is analysed not only with the geometric dimensions of the Manzanares pilot plant but also with SCPP systems created by some researchers in different dimensional characteristics. Toghraie et al. [10] develop a SCPP system with $100 \mathrm{~m}$ chimney height, $100 \mathrm{~m}$ collector radius, $4 \mathrm{~m}$ chimney radius, and $2 \mathrm{~m}$ collector height. They use the standard $\mathrm{k}-\varepsilon$ turbulence model, suggesting that the flow within the system is turbulent so viscous effects can be neglected. They claim through the CFD solutions which they repeat at 600 and $800 \mathrm{~W} / \mathrm{m}^{2}$ solar intensities that increasing the chimney height will increase the power output and efficiency of the system while increasing the collector radius will increase the power output and decrease the efficiency. Similarly, by designing large-scale systems, researchers predict the performance of systems with different chimney heights and collector radius $[11,12]$. In SCPP systems, the floor plays an important role in energy storage and directing the heated air. Attig-Bahar et al. [13] compare the performance of the SCPP system to be installed in the south of Tunisia with the data obtained without energy storage by analysing the effect of using different energy storage materials on the ground. In the study, which takes the pilot plant in Manzanares as a reference, it is proved that when sand, soil, and gravel materials are used for energy storage on the ground, 35\% more power output can be obtained compared to the reference case. Sedighi et al. [14] analyse the effect of the porosity of the soil to be used as an energy storage unit on the performance of the system. He stated that soil porosity is inversely proportional to the yield and output power of the SCPP. They claim that by decreasing the porosity of the soil from 0.4 to 0.1 , the system efficiency and the power output of the turbine increase by 3.04\%. Fadaei et al. [15] conduct an experimental study to examine the effect of the use of phase change material (PCM) on the performance of SCPPs. In the experimental setup with $3 \mathrm{~m}$ chimney height and $3 \mathrm{~m}$ collector diameter, while the air velocity with the traditional solar chimney is $1.9 \mathrm{~m} / \mathrm{s}$, when the PCM is used on the ground, the airflow rate increases by $8.33 \%$ and reaches $2 \mathrm{~m} / \mathrm{s}$. Larbi et al. [16] evaluate the impacts of several parameters on the system performance through a mathematical model by referencing the geometric dimensions of the Manzanares pilot plant. They consider different thicknesses of the water layer on the ground for the purpose of energy storage. They claim that $5 \mathrm{~cm}$ of water thickness is ideal for energy storage performance, and in July, the power output reaches 
$120 \mathrm{~kW}$ in this case. Yaswanthkumar and Chandramohan [17] analyse the effect of energy storage unit (TES) on the performance of SCPPs with the 3D CFD model. They study a system with a collector diameter of $3.5 \mathrm{~m}$ and a chimney height of $6 \mathrm{~m}$ which has a collector entrance height of $0.15 \mathrm{~m}$. They evaluate the performance changes in the system by integrating a $0.15 \mathrm{~m}$ thick energy storage unit with $3.5 \mathrm{~m}$ diameter into this design. It is reported that the air velocity in the system $6.17 \mathrm{~m} / \mathrm{s}$ to $3.9 \mathrm{~m} / \mathrm{s}$ according to the reference situation since TES absorbs some of the energy during the daytime hours. Senbeto [18] examines the effect of TES on the performance of SCPP systems with the CFD model. The standard RNG $\mathrm{k}-\varepsilon$ turbulence model and Boussinesq approximation consider the lifting effects in the model. In his work, which takes the Manzanares prototype as a reference, he claims that the air velocity of the system without a turbine will be $16.5 \mathrm{~m} / \mathrm{s}$ at the chimney inlet for the solar radiation of $1000 \mathrm{~W} / \mathrm{m}^{2}$. It is stated that the power output of the system decreases by approximately $50 \%$ during the sunshine hours due to the energy storage by the water layer. However, the stored energy becomes active after sunset, and the daily power productivity is found to be higher than the reference case. Kalash et al. [19] experimentally investigate the performance of the system with the solar chimney they set up on a sloping ground at Damascus University in Syria. They place the $9 \mathrm{~m}$ high chimney about $3 \mathrm{~m}$ above the ground. They place a $6.04 \mathrm{~m}$ long collector with $3.68 \mathrm{~m}$ inlet width and $0.65 \mathrm{~m}$ outlet width on the sloping ground and connect it with the chimney. They claim that the system yields a temperature increase of $19^{\circ} \mathrm{C}$ in the collector even in winter months and $2.9 \mathrm{~m} / \mathrm{s}$ upward air velocity is measured in the chimney. Bilgen and Rheault [20] make geometric dimensioning for a fixed $950000 \mathrm{~m}^{2}$ collector area and $54 \mathrm{~m}$ chimney diameter for 3 different locations to generate $5 \mathrm{MW}$ power at high latitudes. They state through the annual simulations that the increase in ground inclination angle in different locations will reflect positively on the system. They claim that the chimney height, which is $123 \mathrm{~m}$ for $5 \mathrm{MW}$ power output in the Ottawa location with a ground slope of $38.40^{\circ}$, can be achieved in Edmonton with a ground slope of $48.40^{\circ}$ and a chimney height of $35 \mathrm{~m}$. Cao et al. [21] evaluate the performance of a SCPP system likely to be used on the sloping mountain in Lanzhou climate conditions. Geometric characteristics of the Manzanares pilot plant are adopted in the numerical model. In the simulations carried out for 12 months, they state that the power output for the horizontal ground reaches its highest value in June and will be approximately $60 \mathrm{~kW}$. They claim that the year-round power output will not fall below $80 \mathrm{~kW}$ on sloping ground and will exceed $100 \mathrm{~kW}$ in March. Sivalakshmi et al. [22] carry out an experimental study for solar chimneys. Their research compares the performance of the absorber plate for the cases of being dimpled or flat. Thermal performance comparisons are done according to air temperature, air velocity at the chimney outlet, and heat transfer coefficient. When the experimental results are compared, it is observed that the heat transfer coeffi- cient of the system with dimpled absorber plate in the sunny midday is $13.55 \%$ higher than the system with a flat absorber plate. It is claimed that a similar situation is observed in the air temperature at the chimney outlet. Similar to the ground, the collector slope also affects the performance of the system. Cuce [23] analyses the effect of the collector slope on the system performance, which takes the geometry of the Manzanares pilot plant as a reference. It emphasises that the power output of $54.5 \mathrm{~kW}$ without slope will increase by $4.5 \%$ (to approximately $57 \mathrm{~kW}$ ) when the angle of inclination of the collector is $2^{\circ}$. Different nanoparticles are also utilised in SCPP systems to enhance energy storage performance on the ground. Some researchers claim that the nanoparticle density improves heat transfer in certain situations. It is reported that an increase in Reynolds number in closed loop systems improves heat transfer by increasing the Nusselt number $[24,25]$.

Although different designs of SCPP systems are available in literature, the impacts of the ground slope on the main performance parameters have not been evaluated to date by researchers. Therefore, the goal of this research is to conduct an elaborative numerical analysis with experimental validation in order to study the aforesaid impact in detail. By considering the slope of the collector constant, the influence of the linear rise of the ground from $5 \mathrm{~m}$ inside the collector inlet to the chimney entrance on mass flow rate, power output, dynamic pressure difference, and efficiency is comprehensively examined. DO solar ray tracing algorithm and RNG $\mathrm{k}-\varepsilon$ turbulence model are applied simultaneously to the $3 \mathrm{D}$ symmetric CFD model. Simulations are repeated for different ground angles, following the mesh-independent solution, based on the solar radiation intensity of $1000 \mathrm{~W} / \mathrm{m}^{2}$ and the ambient temperature of $293.15 \mathrm{~K}$ as climatic conditions. Climatic parameters are selected according to the literature data. For instance, when the test results obtained by Haaf [3] from the Manzanares pilot plant are examined, it is seen that the maximum solar radiation during the day is $1000 \mathrm{~W} / \mathrm{m}^{2}$ and the air temperature is around $20^{\circ}$.

\section{Governing Equations}

Based on the geometric dimensions of the pilot plant, the first application of solar chimney power plants, the effects of ground entrance and ground slope on the system are examined in SCPP systems, provided that the chimney entrance height is constant. By keeping the environmental conditions constant in all CFD solutions, by solving the continuity, momentum, energy, and turbulence equations in parallel, the graphs of mass flow rate, dynamic pressure difference around the turbine, and power output are obtained separately in different designs. The following assumptions are made for simplicity and time-saving in the analyses:

(1) System air is considered incompressible

(2) Flow regime is constant, 3D, and turbulent 
(3) Environmental conditions are considered constant in all simulations

(4) Boussinesq model is accepted for density

The conservation equations solved by ANSYS FLUENT are as follows [26]:

(a) Continuity equation

$$
\nabla \cdot(\rho \cdot \vec{v})=0
$$

(b) Momentum equation

$\nabla(\rho \cdot \vec{v} \cdot \vec{v})=-\nabla p+\cdot\left(\mu\left[\left(\nabla \vec{v}+\nabla \vec{v}^{T}\right)-\frac{2}{3} \nabla \cdot \vec{v} I\right]\right)+\rho\{\vec{g}\}$

(c) Energy equation

$$
\nabla \cdot(\vec{v}(\rho E+p))=\nabla \cdot\left(k_{\mathrm{eff}} \nabla T-h \vec{j}+\left(\mu\left[\left(\nabla \vec{v}+\nabla \vec{v}^{T}\right)-\frac{2}{3} \nabla \cdot \overrightarrow{v I}\right] \cdot \vec{v}\right)\right) .
$$

Since there is no forced flow source in SCPP systems, there is heat transfer by natural convection. Rayleigh's equation for natural convection is as follows:

$$
\mathrm{Ra}=\frac{g \beta \Delta T H_{c}^{3}}{\alpha v}
$$

where $H_{c}$ refers to the collector height, $v$ is the kinematic viscosity, and $\alpha$ expresses the thermal diffusion coefficient. The preliminary findings reveal that Ra number takes a notably greater value than $10^{9}$, which is a critical value, and hence, the flow inside the system is accepted as turbulent [23]. There are 3 different $\mathrm{k}-\varepsilon$ turbulence models in ANSYS FLUENT software. In the current research, the RNG k- $\varepsilon$ turbulence model is used, which gives better results in vortex flows [27]. The equations of the model are as follows:

$$
\frac{\partial}{\partial x_{i}}\left(\rho k u_{i}\right)=\frac{\partial}{\partial x_{j}}\left[\alpha_{k} \mu_{e f f} \frac{\partial k}{\partial x_{j}}\right]+G_{k}+G_{b}+\rho \varepsilon-Y_{M}+S_{k},
$$

$$
\begin{aligned}
& \frac{\partial}{\partial x_{i}}\left(\rho \varepsilon u_{i}\right)=\frac{\partial}{\partial x_{j}}\left[\alpha_{\varepsilon} \mu_{e f f} \frac{\partial \varepsilon}{\partial x_{j}}\right]+C_{1_{\varepsilon}} \frac{\varepsilon}{k}\left(G_{k}+C_{3 \varepsilon} G_{b}\right) \\
& -C_{2 \varepsilon} \rho \frac{\varepsilon^{2}}{k}-R_{e}+S_{\varepsilon} .
\end{aligned}
$$

When the experimental studies on SCPP systems are examined, it is seen that the temperature of the air in the sys- tem does not change much [3]. In this case, the Boussinesq model can be used for density $[6,22]$. Its equation is as follows:

$$
\left(\rho-\rho_{a}\right) g \approx-\rho_{a} \beta\left(T-T_{a}\right) g
$$

In Equation (7), $\beta$ is the thermal expansion coefficient, and $\rho_{a}$ and $T_{a}$ are the density and temperature of the system air at the collector inlet. The collector supplies thermal energy to the system which can be expressed by

$$
\dot{Q}=\dot{m} C_{p} \Delta T
$$

In Equation (8), the temperature increase along the collector is represented by $\Delta T$. When the total collector surface area is $A_{\text {coll }}$ and incoming solar radiation is $G$, collector efficiency can be defined as follows:

$$
\eta_{\text {coll }}=\frac{\dot{Q}}{A_{\text {coll }} G}
$$

Different calculations of the power output in SCPPs are available in the literature. Usually, the power output calculation is done through the pressure drop $\left(\Delta P_{t}\right)$ in the turbine [28]. In this study, the following equation is used for the power output of the system:

$$
P_{o}=\eta_{t} \Delta P_{t} Q_{v} .
$$

In Equation (10), $\eta_{t}$ is the turbine-generator efficiency and taken as 0.8 [28]. Although there are different parameters that affect the performance of SCPPs, the two main factors that determine the power output are the pressure drop $\left(\Delta P_{t}\right)$ in the turbine and the volumetric flow rate $\left(Q_{v}\right)$ [28]. In this study, the turbine pressure drop is obtained from the average pressure $\left(\Delta P_{t}\right)$ where the turbine is placed in the CFD simulation results and is calculated as follows:

$$
\Delta P_{t}=r_{t} P_{t}
$$

Here, $r_{t}$ is considered as the turbine pressure drop rate [29]. Moreover, the efficiency of the system can be calculated as follows:

$$
\eta=\frac{P_{o}}{A_{\text {coll }} G}
$$

\section{CFD Model and System Properties}

The geometric and climatic parameters that affect the performance of SCPP systems are studied by different researchers in the literature. However, in this study, the performance of the pilot plant at different values of the ground slope is examined for the first time in literature. The study is based on the main dimensions of the Manzanares prototype, Spain, and simulations are carried out for constant environmental conditions. The geometric dimensions and configuration details of the system are given in Table 1 [30]. In the analyses, the 
TABLE 1: Structural details of the pilot plant in Manzanares [28].

\begin{tabular}{lc}
\hline Parameter & Value \\
\hline Average collector height & $1.85 \mathrm{~m}$ \\
Average collector radius & $122.0 \mathrm{~m}$ \\
Chimney radius & $5.08 \mathrm{~m}$ \\
Chimney height & $194.6 \mathrm{~m}$ \\
Ground thickness & $0.5 \mathrm{~m}$ \\
\hline
\end{tabular}

outlet height is changed provided that the entrance height of the horizontally placed collector is kept constant.

Simulations are repeated at different angle values. In this study, the influence of ground slope on the system performance of SCPPs is investigated by a reliable commercial software ANSYS FLUENT. In the CFD study, a successful 3D model is initially created, and its accuracy and reliability are justified through in situ measurements. In the model developed with reference to the Manzanares prototype, onequarter of the whole solution domain is taken into consideration to minimise the iteration period. The model has two plane symmetries (XZ and YZ planes). Since it is seen that the temperature does not change from a certain point in the experimental measurements conducted on the prototype before, the ground thickness is taken as $0.5 \mathrm{~m}$ [3]. While designing the model, the ground slope is started within $5 \mathrm{~m}$ of the collector input. The slope that starts at this point ends at the collector exit. This is the case for the whole system. In simulations, after the results are obtained for the uneven ground condition, the ground slope is changed between 0.1 and 0.5 degrees. While changing the ground slope, the starting point of the slope is kept constant and the end point is the collector outlet. Since the pressure difference created by the collector inlet and the pressure difference at the chimney outlet is very small, 0 is ignored. The temperature at the collector inlet is taken equal to the ambient temperature. The schematic of the sloping ground SCPP design is illustrated in Figure 1.

Based on the adiabatic boundary condition at the ground and the chimney wall, the heat transfer coefficient is taken as $0 \mathrm{~W} / \mathrm{m}^{2} \mathrm{~K}$, while the heat transfer coefficient between the collector and the system air is assumed to be $10 \mathrm{~W} / \mathrm{m}^{2} \mathrm{~K}$. Physical properties of chimney, collector, and ground materials are very important in numerical modelling of solar chimney power plants and directly affect the simulation results. Model parameters of the relevant parts are given in Table 2. In addition, environmental parameters and thermophysical properties of the system air used in modelling are given in detail in Table 3. Due to the dimensional characteristics of the study, numerical modelling is carried out in a very dense cell number, which can extend the iteration time up to 6 hours for each parametric study. In order to shorten the iteration period, instead of the whole geometry, a quarterly axial symmetric model is preferred in the research.

Simulations are carried out with ANSYS FLUENT software, which uses the finite volume method in discretization of governing equations. The RNG k- $\varepsilon$ turbulence model is preferred in the solution of the momentum equation. The SIMPLE algorithm is used to specify the relationship between

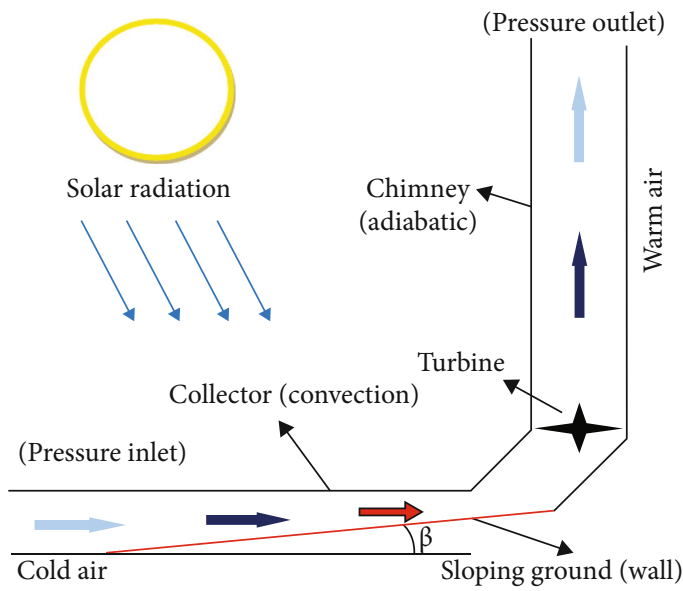

FIGURE 1: SCPP with sloping ground and corresponding boundary conditions.

TABle 2: Physical properties of the materials used in the CFD research [8].

\begin{tabular}{lccc}
\hline Physical property (unit) & Glass & Ground & Chimney \\
\hline Density $\left(\mathrm{kg} \cdot \mathrm{m}^{-3}\right)$ & 2500 & 2160 & 2719 \\
Thermal conductivity $\left(\mathrm{W} \cdot \mathrm{m}^{-1} \mathrm{~K}^{-1}\right)$ & 1.15 & 1.83 & 202.4 \\
Specific heat capacity $\left(\mathrm{J} \cdot \mathrm{kg}^{-1} \mathrm{~K}^{-1}\right)$ & 750 & 710 & 871 \\
Transmissivity & 0.9 & Opaque & Opaque \\
Absorption coefficient & 0.03 & 0.9 & 0 \\
Refractive index & 1.526 & 1 & 1 \\
Emissivity & 0.1 & 0.9 & 1 \\
Thickness (m) & 0.004 & 0.5 & 0.00125 \\
\hline
\end{tabular}

TABLE 3: CFD parameters and climatic characteristics [8].

\begin{tabular}{lc}
\hline Solar radiation $\left(\mathrm{W} \cdot \mathrm{m}^{-2}\right)$ & 1000 \\
\hline Atmospheric pressure $(\mathrm{Pa})$ & 101325 \\
Ambient temperature $(\mathrm{K})$ & 293.15 \\
Ambient air density $\left(\mathrm{kg} \cdot \mathrm{m}^{-3}\right)$ & 1.2046 \\
Gravitational acceleration $\left(\mathrm{m} \cdot \mathrm{s}^{-2}\right)$ & 9.81 \\
Air conductivity $\left(\mathrm{W} \cdot \mathrm{m}^{-1} \mathrm{~K}^{-1}\right)$ & 0.0259 \\
Ideal gas constant $\left(\mathrm{J} \cdot \mathrm{kg}^{-1} \mathrm{~K}^{-1}\right)$ & 287 \\
Kinematic viscosity of air $\left(\mathrm{m} \cdot \mathrm{s}^{-2}\right)$ & $1.48 \times 10^{-5}$ \\
Air heat capacity $\left(\mathrm{J} \cdot \mathrm{kg}^{-1} \mathrm{~K}^{-1}\right)$ & 1006.43 \\
Turbine pressure drop ratio & $2 / 3$ \\
Stefan-Boltzmann constant $\left(\mathrm{W} \cdot \mathrm{m}^{-2} \mathrm{~K}^{-4}\right)$ & $5.667 \times 10^{-8}$ \\
\hline
\end{tabular}

pressure and air velocity. The PRESTO approach is preferred for pressure interpolation. Governing equations are discretized by the second-order UPWIND method. The DO radiation model is applied with solar ray tracing technique. The Boussinesq method is adopted to calculate the change in density of the air in the system. In the analyses, $10^{-6}$ is considered appropriate as the criteria for convergence. For the numerical procedure, first of all, the horizontal ground is modelled with the geometric dimensions of the Manzanares pilot plant. Then, a CFD simulation is performed with the proposed 
climatic parameters. The simulation results are compared with the experimental data in the reference situation. If the numerical results are not consistent with the experimental data, the simulation is repeated. In case of the sufficient justification between numerical and experimental results, the model geometry is changed and the new simulation results are produced. The flow chart of the calculation procedure followed in the study is given in Figure 2.

\section{Results and Discussion}

Before the simulations are repeated for different slope angle values, the mesh-independent solution is examined. For this purpose, the mesh quality and mesh-independent solution are confirmed for three different cell numbers by considering the maximum air velocity $\left(V_{\max }\right)$ in the system. Table 4 shows the changes in the value of $V_{\max }$ for different cell numbers. For the cell number of 386041, the change in $V_{\max }$ is determined to be $1.4 \%$ only compared to the cell number case of 305619. From this point, the rest of the calculations are done over the cell number of 386041. Model and mesh visuals are given in Figure 3. After the justification of the mesh-free solution, the reliability of the numerical results is evaluated by comparing the CFD findings with the in situ measurements and other well-documented numerical models over the power output $\left(P_{o}\right)$ figures of the system. It is perspicuous from Figure 4 that the numerical methodology adopted in this research is in good agreement with both experimental [31] and numerical results [6] when $P_{o}$ values are taken into consideration for different solar intensities. Afterwards, simulations of the pilot plant with different ground slopes are carried out with the CFD model, whose mesh-independent solution is obtained and reliability is verified. Type, quality, and intensity of meshing are of vital importance in CFD analyses. Convergence, coherency, and reliability are notably affected by the aforesaid effects as well as discretization techniques. If the previous numerical findings of other researchers given in Figure 4 are examined, it is observed that the numerical approach adopted in the present study is more adaptive to the experimental data due to the abovementioned factors [32].

The most important variables in calculating the power output of solar chimney power plants are volumetric flow rate and turbine pressure drop. The air velocity and the pressure distribution, on which the volumetric flow rate depends, are therefore extremely important. With this approach, while examining the effect of ground slope on the performance parameters of the Manzanares pilot plant, pressure and airflow velocity distributions are especially investigated. The pressure distributions in the Manzanares prototype of horizontal and sloping $\left(0.5^{\circ}\right)$ ground are shown in Figure 5. When the pressure gradients in the existing system are examined, it is seen that it becomes more apparent in general towards the chimney inlet. It is clearly seen that the pressure jumps are more in the area between the collector outlet called the throat and the chimney inlet. This can be attributed to the intensive turbulence effects around the throat and chimney inlet. Considering that the turbine is located at a height of $9 \mathrm{~m}$ from the ground in the Manzanares pilot plant, the

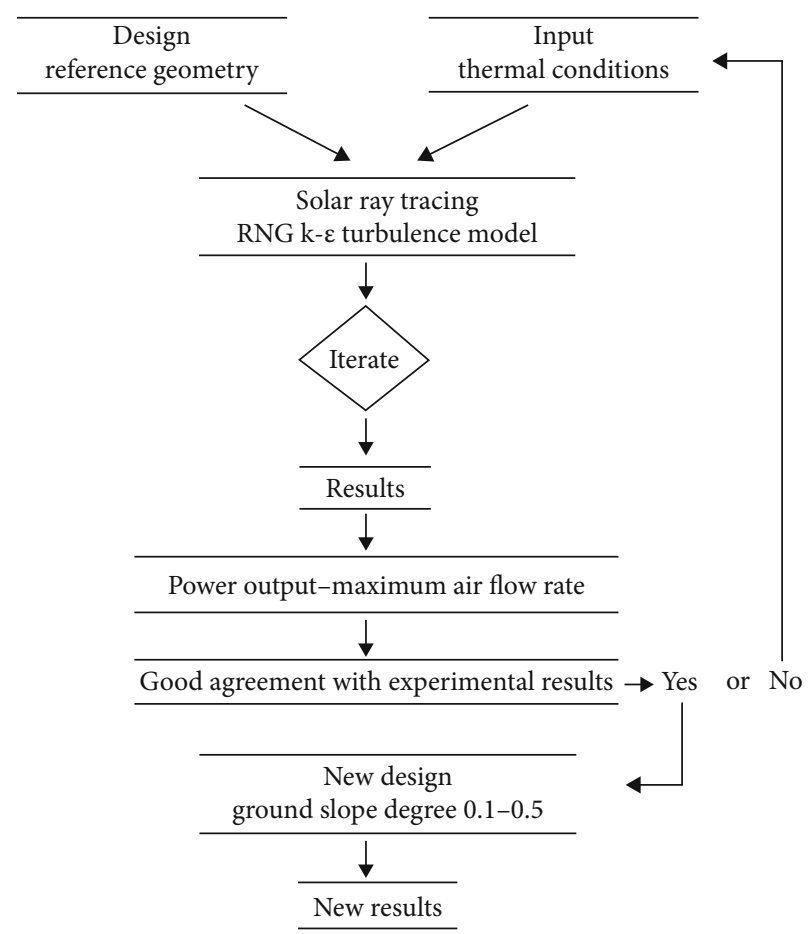

Figure 2: Experimental procedure.

TABLE 4: Mesh-independent solution over maximum air velocity.

\begin{tabular}{lcc}
\hline Cell count & Maximum air velocity $(\mathrm{m} / \mathrm{s})$ & \% change \\
\hline 259800 & 14.42 & - \\
305619 & 13.996 & 2.9 \\
386041 & 14.202 & 1.4 \\
\hline
\end{tabular}

chimney entrance and its upper part where the pressure difference is maximum coincide here. This allows more power output with greater pressure difference. As the system is open to the atmosphere towards the chimney outlet, it is seen that the pressure value is equal to zero. On sloping ground compared to nonsloping case, the lifting effects are enhanced by the design in an upward direction. This yields to higher air velocities at the throat compared to the horizontal ground. In this case, the mass flow rate is expected to increase, but narrowing the airflow area at the throat with the increase of the ground slope causes a decrease in the mass flow rate. Considering the power output calculation, this is expected to have a negative effect on the system, but sloping ground yields to notable increase in the pressure difference in the throat. In this way, it is seen that higher power is delivered from the system. In the reference state, it is seen that the place where the pressure difference is the highest is the entrance of the chimney. When the ground slope is configured as $0.5^{\circ}$, it is observed that the pressure difference gets the highest value at the collector outlet.

The distribution of the air velocity in the system is given in Figure 6. In the reference state, the maximum air velocity is $14.20 \mathrm{~m} / \mathrm{s}$ on the ground without slope, and when the ground slope angle is $0.5^{\circ}$, it increases by $37.4 \%$ to $19.51 \mathrm{~m} / \mathrm{s}$. This can be ascribed to the enhanced turbulence effects and improved 


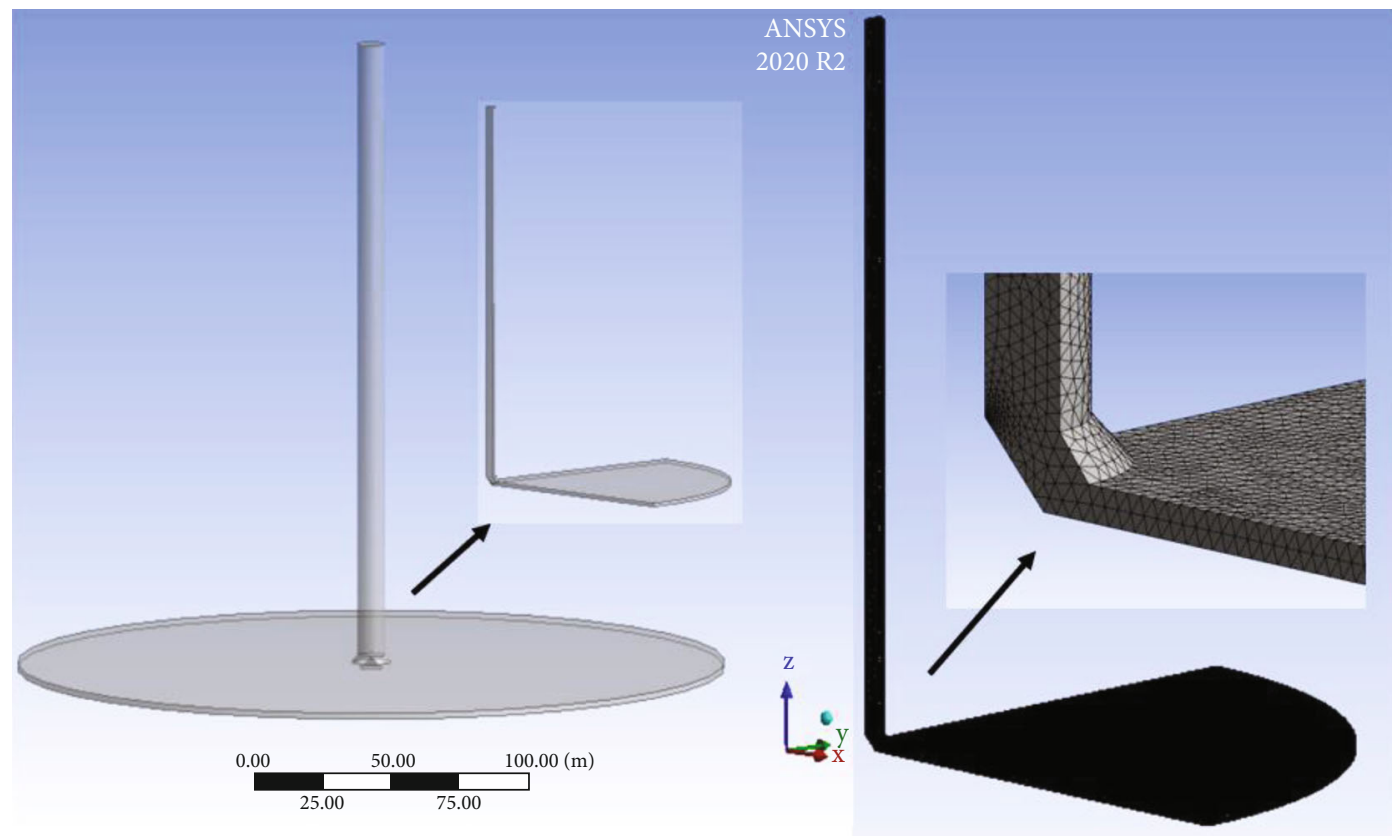

Figure 3: Model and mesh visuals.

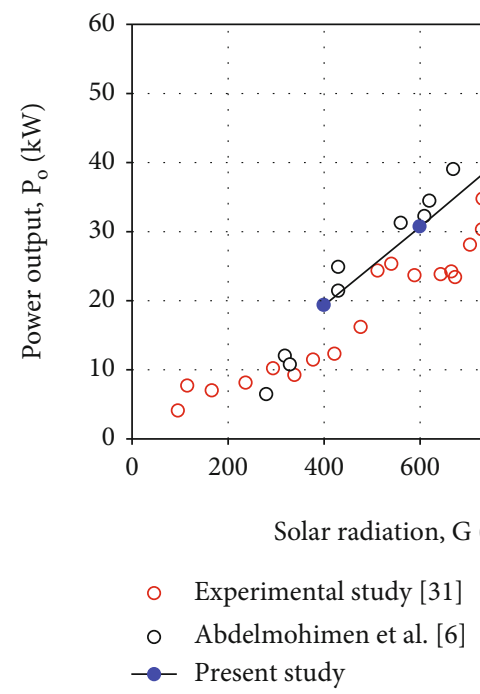

FIgure 4: Accuracy justification of the CFD results over $P_{o}$ values under different solar intensities.

lifting forces near the throat. While the air velocity in the system increases with the slope angle, it is the opposite of the mass flow rate figures. This is because of the narrowed cross-sectional area with the sloping design. The mass flow rate, which is $1117.9 \mathrm{~kg} / \mathrm{s}$ for the nonsloping system, decreases exponentially with angle. For the slope ranges of $0-0.5^{\circ}$, the mass flow rate of the system can be obtained from the following equation:

$$
\dot{m}=1118-106.6 \beta-264.5 \beta^{2}-1129 \beta^{3} .
$$

The variation of $\dot{m}$ with ground slope $(\beta)$ is illustrated in Figure 7. Due to the narrowing volume beneath the collector with the increasing ground slope, a considerable decrease in mass flow rate figures is observed. In Equation (13), $\beta$ is the ground inclination angle. When the ground inclination angle is $0.5^{\circ}$, it is seen that the mass flow rate decreases $32.29 \%$ compared to the reference situation and equals to $857.452 \mathrm{~kg} / \mathrm{s}$. The mass flow rate of the system decreases exponentially as the ground inclination angle increases. This causes the power output to decrease, but the increase in the turbine pressure drop will tolerate this situation. For this reason, for the optimum power output assessment, the $0-0.5$ range of the ground slope is analysed by considering the mass flow rate and pressure difference. Another important parameter in the performance of SCPPs is the pressure drop. Increasing the pressure drop across the turbine directly increases the power output of the system. In the reference state, the pressure drop across the turbine is $109.777 \mathrm{~Pa}$. Increasing the ground slope angle exponentially improves the pressure drop across the turbine. The pressure drop can be interacted with the ground inclination angle by the following equation:

$$
\Delta P_{\text {dyn }}=\frac{-109.8+366.1 \beta}{1-4.029 \beta+2.319 \beta^{2}} .
$$

When the ground inclination angle is $0.5^{\circ}$, it is seen that the pressure drop across the turbine increases by $53.45 \%$ compared to the reference situation and becomes $-168.456 \mathrm{~Pa}$. This impact can be clearly seen in Figure 8 . The element that causes pressure difference in solar chimney power plants is the chimney. With the ground slope, it is seen that there is a pressure difference in the system due to both the ground geometry and the chimney. There is a clear increase in the pressure difference within the system due to the ground slope. Increasing the ground slope increases the pressure difference and therefore the power output. The parameters that affect the power output of SCPPs are analysed many times in the literature by 

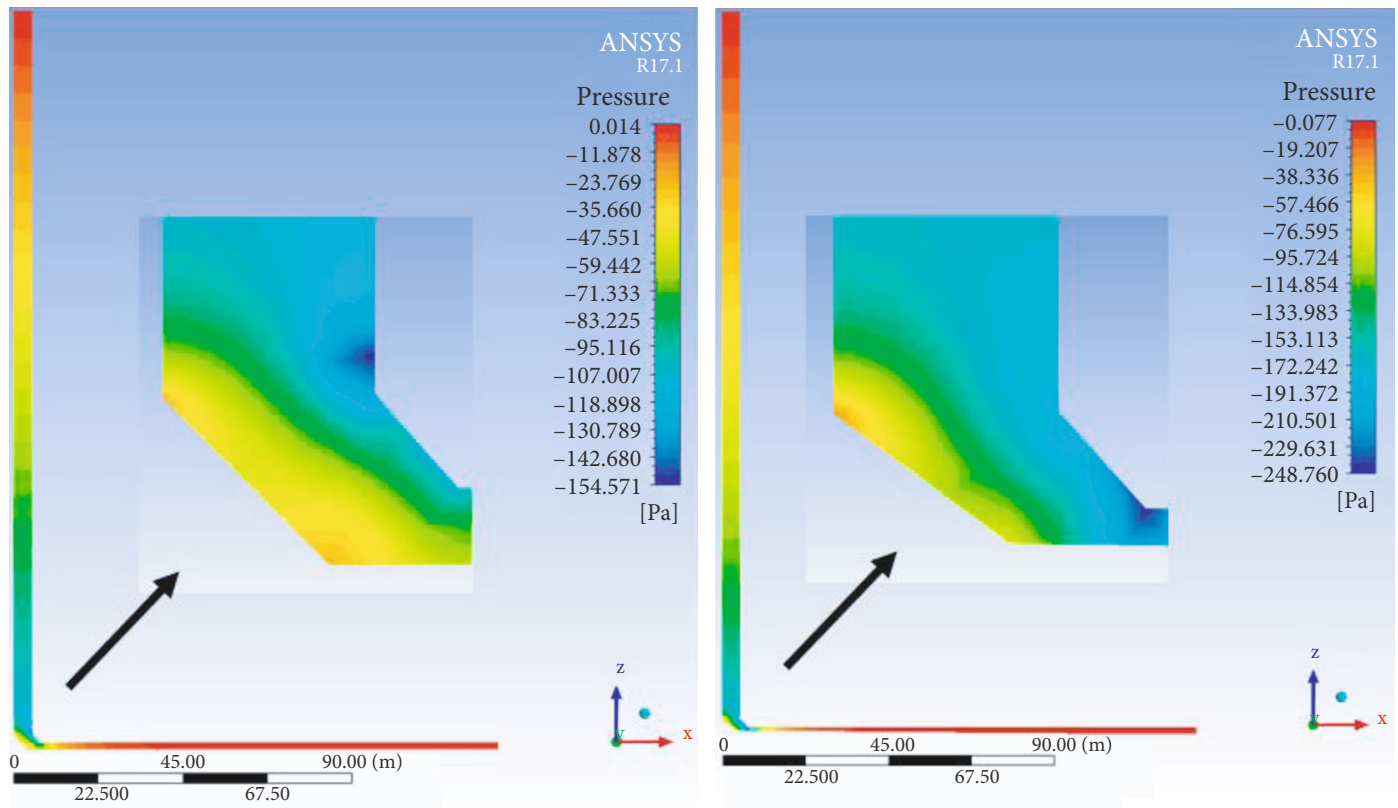

FIgURE 5: Pressure distributions in the pilot plant for horizontal (left) and sloping $\left(0.5^{\circ}\right)$ ground (right).
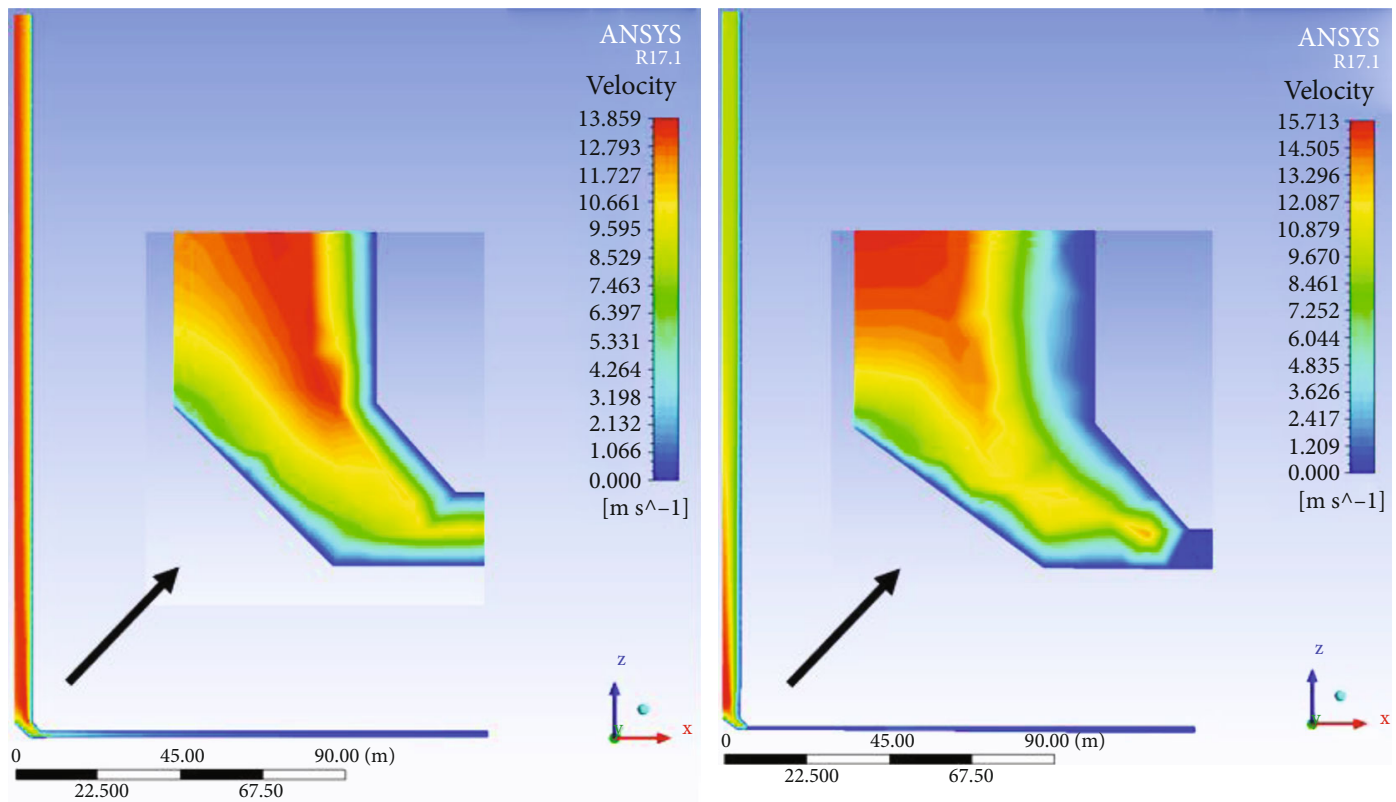

Figure 6: Velocity distributions in the pilot plant for horizontal (left) and sloping $\left(0.5^{\circ}\right)$ ground (right).

different researchers. In this study, the effect of ground inclination angle, which is not studied in the literature, on the performance of the system is analysed. It is seen that the system, which gives a power output of $54.3 \mathrm{~kW}$ in the reference state, increases exponentially with the increase in the ground inclination angle, so this effect has a positive effect on the system as shown in Figure 9. The power output of the system in the range of $0-0.5^{\circ}$ ground slope angle can be calculated from the following equation:

$$
P_{o}=54.48+37.42 \beta-37.02 \beta^{2} .
$$

When the ground slope angle is made $0.5^{\circ}$, it is seen that the power output is $63.95 \mathrm{~kW}$, increasing by $17.7 \%$ compared to the reference situation. The increase in power output with ground slope is very apparent between the reference state and a $0.1^{\circ}$ slope. There is a $7.15 \%$ increase in power output at $0.1^{\circ}$ ground slope compared to the reference situation. This percentage gradually decreases in the same degree intervals and falls below $1 \%$ after $0.4^{\circ}$. For this reason, the effect of ground slope on power output has been examined in the range of $0-0.5^{\circ}$, which is seen as the critical range. Apart from the analysed part in the study, examining the parameters affecting the system together for a more detailed optimisation will give 


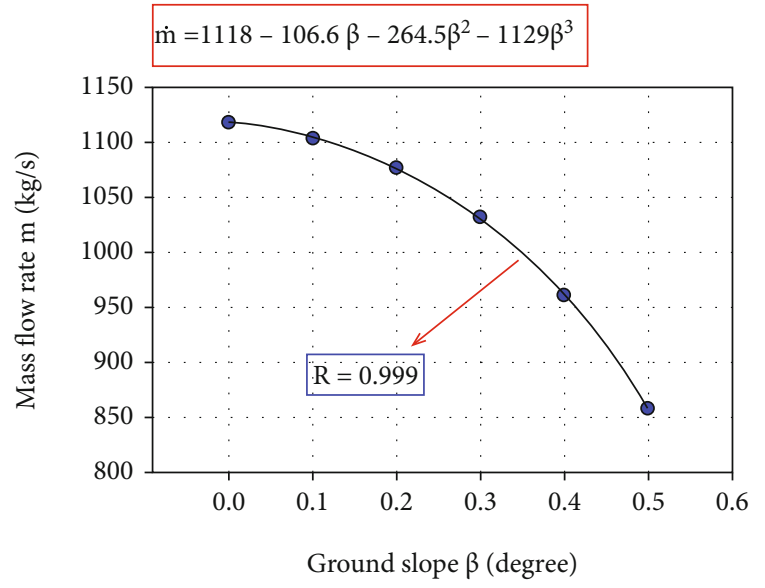

Figure 7: Mass flow rates in the pilot plant for different ground slope angles.

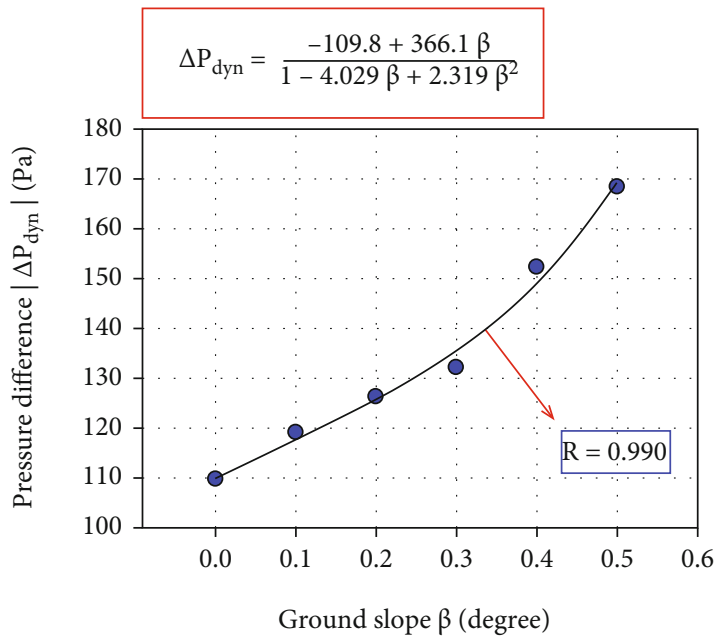

FIGURE 8: Dynamic pressure difference across the turbine for different ground slope angles.

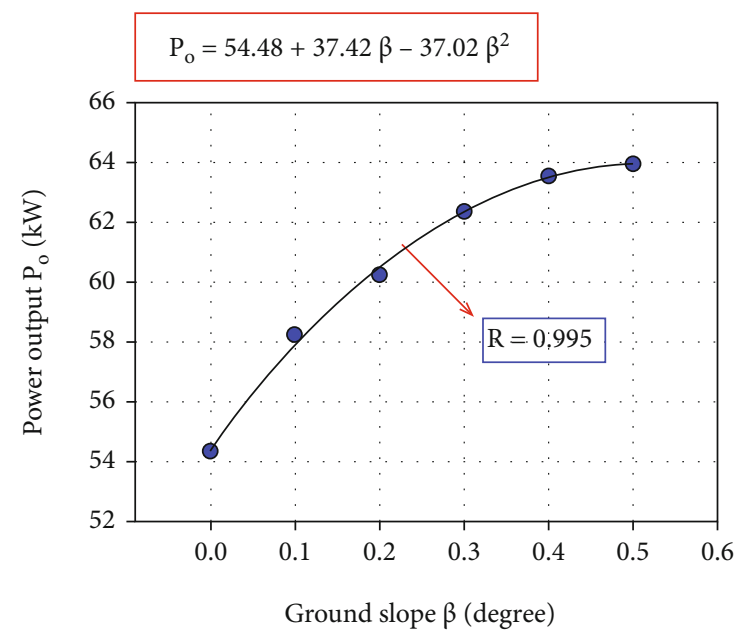

Figure 9: Power output of the pilot plant for different ground slope angles.
TABLE 5: Rayleigh number for 0 and $0.2^{\circ}$ ground slope.

\begin{tabular}{lcc}
\hline Ground slope (degree) & Rayleigh number & \% change \\
\hline 0 & $8.517 \times 10^{9}$ & - \\
0.2 & $8.769 \times 10^{9}$ & 2.95 \\
\hline
\end{tabular}

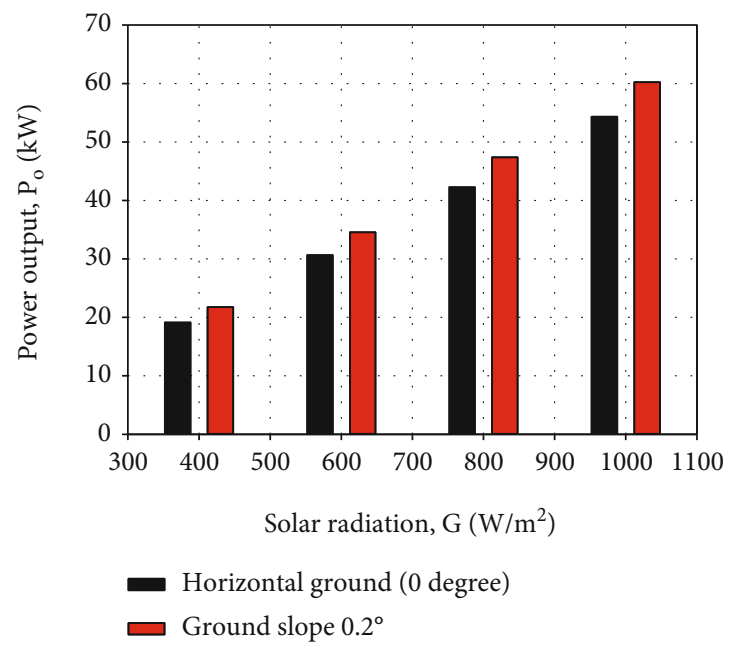

FIgURE 10: Comparison of power outputs for horizontal and $0.2^{\circ}$ sloping ground under different solar radiation conditions.

more reliable results. For this reason, the effect of more than one parameter on the system can be examined with a more detailed study in future works.

For readers' interest, it is useful to clarify the reason of making a range selection for ground slope up to $0.5^{\circ}$. When the plot for power output versus slope of the ground is examined, it is easily understood that there are insignificant changes in power output after the slope value of $0.2^{\circ}$. This output is achieved through a preliminary analysis. Then, the analysis is extended to further slope values and observed that $0.5^{\circ}$ is a critical value for the power output. After achieving this output, parametric research is conducted, and increment in ground slope is taken to be $0.1^{\circ}$ to clearly illustrate the tendency of the interaction between power output and ground slope. $R$ value is calculated to be 0.995 in the regression analysis, which proves the appropriateness of the increment in slope value.

In the study, it is clearly seen that the power output increases with the ground slope. Rayleigh (Ra) number increasing with the slope of the ground improves the heat transfer under the collector. The comparison of the Ra number for the reference case and the ground slope of $0.2^{\circ}$ is given in Table 5. It is seen that the power outputs for the horizontal and sloping ground increase with the solar intensity. The aforesaid comparison is given in Figure 10. When the graph is examined, it can be easily asserted that taking the solar radiation of $1000 \mathrm{~W} / \mathrm{m}^{2}$ aims to show the maximum situation. The results unequivocally indicate that sloping ground gives better performance figures than horizontal ground for each solar intensity level. 


\section{Conclusions}

The impact of ground slope on the main performance parameters of SCPPs is analysed for the first time in literature. The numerical methodology is structured on the material and geometric properties of the pilot SCPP system, and accuracy verification is done over the in situ measurements. A 3D axisymmetric CFD approach is proposed based on a DO solar ray tracing algorithm with the RNG k- $\varepsilon$ turbulence technique. Following remarks might be achieved from the study:

(1) DO solar ray tracing algorithm supported by the RNG $k-\varepsilon$ turbulence model is found to be an ideal numerical methodology in vortex flows which take place in SCPPs

(2) When the incoming solar radiation is equal to $1000 \mathrm{~W} / \mathrm{m}^{2}, V_{\max }$ is determined to be $14.2 \mathrm{~m} / \mathrm{s}$, which shows a well-accordance with the in situ tests of $15.0 \mathrm{~m} / \mathrm{s}$

(3) Ground slope angle $(\omega)$ is an effective parameter on main performance characteristics of SCPPs

(4) Mass flow rate of air shows an experimental decrease with increasing ground slope. $\dot{m}$ is $1117.9 \mathrm{~kg} / \mathrm{s}$ for the nonsloping system. When $\omega$ is $0.5^{\circ}$, it is seen that $\dot{m}$ decreases $32.29 \%$ compared to the horizontal ground and equals to $857.452 \mathrm{~kg} / \mathrm{s}$

(5) On the contrary to $\dot{m}$, dynamic pressure difference across the turbine is remarkably improved with increasing $\omega$. In the horizontal ground, $\Delta P_{\mathrm{dyn}}$ across the turbine is found to be $-109.777 \mathrm{~Pa}$. When $\omega$ is $0.5^{\circ}$, it is observed that $\Delta P_{\text {dyn }}$ across the turbine increases by $53.45 \%$ compared to the reference case and equals to $-168.456 \mathrm{~Pa}$

(6) Power output $\left(P_{o}\right)$ in SCPPs can be noticeably enhanced with the design of sloping ground. $P_{o}$ is determined to be $54.3 \mathrm{~kW}$ in the case of horizontal ground. However, when $\omega$ is $0.5^{\circ}$, it is improved to $63.95 \mathrm{~kW}$, increasing by $17.7 \%$ compared to the reference case

(7) The ideal power output $\left(P_{o}\right)$ of the system can be achieved by optimising the mass flow rate and pressure difference across the turbine. When the ground slope is $0.1^{\circ}$, the power output increases by $7.15 \%$ compared to the reference situation, and this is the highest value compared to the other slope increases. A similar situation is valid for the pressure difference across the turbine. When the ground slope is $0.1^{\circ}$, the pressure difference across the turbine increases by $8.52 \%$ compared to the reference case

(8) The increase in power output continues to decrease after $0.1^{\circ}$. The increase in power output falls below $1 \%$ after the ground inclination angle of $0.4^{\circ}$

(9) In further works, sloping ground design in SCPPs will be studied along with the divergent chimney geometry [33] for extra improvement in performance figures

\section{Nomenclature}

$A_{\text {coll }}:$ Collector area $\left(\mathrm{m}^{2}\right)$

$C_{p}: \quad$ The specific heat capacity (J/kg.K)

g: $\quad$ Gravitational acceleration $\left(\mathrm{m} / \mathrm{s}^{2}\right)$

G: $\quad$ Solar radiation $\left(\mathrm{W} / \mathrm{m}^{2}\right)$

$P_{o}: \quad$ Power output (W)

$T: \quad$ Temperature $(\mathrm{K})$

$P_{t}: \quad$ Average pressure at the turbine location $(\mathrm{Pa})$

$\dot{Q}: \quad$ Heat transfer rate $(\mathrm{W})$

$Q_{v}: \quad$ Volumetric flow rate $\left(\mathrm{m}^{3} / \mathrm{s}\right)$

$r_{t}: \quad$ Turbine pressure drop rate

Greek Letters

$\alpha: \quad$ Ambient

$\beta$ : $\quad$ Ground slope degree $\left({ }^{0}\right)$

$\eta_{\text {coll }}:$ Collector efficiency

$\rho: \quad$ Density $\left(\mathrm{kg} / \mathrm{m}^{3}\right)$

$\omega: \quad$ Thermal expansion coefficient $(1 / \mathrm{K})$

\section{Data Availability}

The numerical data used to support the findings of this study are included within the article.

\section{Conflicts of Interest}

The authors have no conflicts of interest to declare.

\section{References}

[1] H. Sen and E. Cuce, "Dynamic pressure distributions in solar chimney power plants: a numerical research for the pilot plant in Manzanares, Spain," WSSET Newsletter, vol. 12, no. 1, pp. 2-2, 2020.

[2] E. Cuce and H. Sen, "Dünden bugüne güneş bacası güç santralleri: Sistem güç çıkışına etki eden performans parametreleri," Avrasya, vol. 7, pp. 256-262, 2020.

[3] W. Haaf, "Solar chimneys: part II: preliminary test results from the Manzanares pilot plant," International Journal of Sustainable Energy, vol. 2, no. 2, pp. 141-161, 1984.

[4] A. Dhahri, A. Omri, and J. Orfi, "Numerical study of a solar chimney power plant," Research Journal of Applied Sciences, Engineering and Technology, vol. 8, no. 18, pp. 1953-1965, 2014.

[5] M. T. Esfidani, S. Raveshi, M. Shahsavari, and A. Sedaghat, "Computational study on design parameters of a solar chimney," in International Conference on Sustainable Mobility Applications, Renewables and Technology (SMART),, pp. 2325, Kuwait, November 2015.

[6] M. A. H. Abdelmohimen and S. A. Algarni, "Numerical investigation of solar chimney power plants performance for Saudi Arabia weather conditions," Sustainable Cities and Society, vol. 38, pp. 1-8, 2018.

[7] J. Li, P. Guo, and Y. Wang, "Effects of collector radius and chimney height on power output of a solar chimney power plant with turbines," Renewable Energy, vol. 47, pp. 21-28, 2012.

[8] E. Cuce, H. Sen, and P. M. Cuce, "Numerical performance modelling of solar chimney power plants: influence of 
chimney height for a pilot plant in Manzanares, Spain," Sustainable Energy Technologies and Assessments, vol. 39, article 100704, 2020.

[9] P. Karimipour Fard and H. Beheshti, "Performance enhancement and environmental impact analysis of a solar chimney power plant: twenty-four-hour simulation in climate condition of Isfahan province, Iran," International Journal of Engineering, vol. 30, no. 8, pp. 1260-1269, 2017.

[10] D. Toghraie, A. Karami, M. Afrand, and A. Karimipour, "Effects of geometric parameters on the performance of solar chimney power plants," Energy, vol. 162, pp. 1052-1061, 2018.

[11] Y. J. Choi, D. H. Kam, Y. W. Park, and Y. H. Jeong, "Development of analytical model for solar chimney power plant with and without water storage system," Energy, vol. 112, pp. 200207, 2016.

[12] X. Zhou, F. Wang, J. Fan, and R. M. Ochieng, "Performance of solar chimney power plant in Qinghai-Tibet Plateau," Renewable and Sustainable Energy Reviews, vol. 14, no. 8, pp. 22492255, 2010.

[13] F. Attig-Bahar, M. Sahraoui, M. S. Guellouz, and S. Kaddeche, "Effect of the ground heat storage on solar chimney power plant performance in the South of Tunisia: case of Tozeur," Solar Energy, vol. 193, pp. 545-555, 2019.

[14] A. A. Sedighi, Z. Deldoost, and B. M. Karambasti, "Effect of thermal energy storage layer porosity on performance of solar chimney power plant considering turbine pressure drop," Energy, vol. 194, p. 116859, 2020.

[15] N. Fadaei, A. Kasaeian, A. Akbarzadeh, and S. H. Hashemabadi, "Experimental investigation of solar chimney with phase change material (PCM)," Renewable Energy, vol. 123, pp. 26$35,2018$.

[16] S. Larbi, A. Bouhdjar, K. Meliani, A. Taghourt, and H. Semai, "Solar chimney power plant with heat storage system performance analysis in South Region of Algeria," in 2015 3rd International Renewable and Sustainable Energy Conference (IRSEC), pp. 1-6, Marrakech, Morocco, December 2015.

[17] A. Yaswanthkumar and V. P. Chandramohan, "Numerical analysis of flow parameters on solar updraft tower (SUT) with and without thermal energy storage (TES) system," Journal of Thermal Analysis and Calorimetry, vol. 136, no. 1, pp. 331343, 2019.

[18] M. Senbeto, "Numerical simulations of solar chimney power plant with thermal storage," International Journal of Engineering Research \& Technology (IJERT), vol. 9, no. 10, pp. 103-106, 2020.

[19] S. Kalash, W. Naimeh, and S. Ajib, "Experimental investigation of the solar collector temperature field of a sloped solar updraft power plant prototype," Solar Energy, vol. 98, pp. 70-77, 2013.

[20] E. Bilgen and J. Rheault, "Solar chimney power plants for high latitudes," Solar Energy, vol. 79, no. 5, pp. 449-458, 2005.

[21] F. Cao, H. Li, Y. Zhang, and L. Zhao, "Numerical simulation and comparison of conventional and sloped solar chimney power plants: the case for Lanzhou," The Scientific World Journal, vol. 2013, Article ID 852864, 8 pages, 2013.

[22] S. Sivalakshmi, V. Sethupathi, and M. Pachiyannan, "A Comparative Analysis on the Thermal Performance of Solar Chimney with Smooth and Dimpled Absorber Plate," Materials Today: Proceedings, vol. 43, pp. 1124-1127, 2020.

[23] E. Cuce, "Güneş bacası güç santrallerinde toplayıcı eğiminin çıkış gücüne ve sistem verimine etkisi," Uludağ Üniversitesi
Mühendislik Fakültesi Dergisi, vol. 25, no. 2, pp. 1025-1038, 2020.

[24] R. Hosseinnezhad, O. A. Akbari, H. H. Afrouzi, M. Biglarian, A. Koveiti, and D. Toghraie, "Numerical study of turbulent nanofluid heat transfer in a tubular heat exchanger with twin twisted-tape inserts," Journal of Thermal Analysis and Calorimetry, vol. 132, no. 1, pp. 741-759, 2018.

[25] O. Rezaei, O. A. Akbari, A. Marzban, D. Toghraie, F. Pourfattah, and R. Mashayekhi, "The numerical investigation of heat transfer and pressure drop of turbulent flow in a triangular microchannel," Physica E: Low-dimensional Systems and Nanostructures, vol. 93, pp. 179-189, 2017.

[26] ANSYS FLUENT, Users Theory Guide, ANSYS, Inc., USA, 2013.

[27] A. Hassan, M. Ali, and A. Waqas, "Numerical investigation on performance of solar chimney power plant by varying collector slope and chimney diverging angle," Energy, vol. 142, pp. 411425, 2018.

[28] T. Ming, R. K. Richter, F. Meng, T. Pan, and W. Liu, "Chimney shape numerical study for solar chimney power generating systems," International Journal of Energy Research, vol. 37, no. 4, pp. 310-322, 2013.

[29] J. Li, H. Guo, and S. Huang, "Power generation quality analysis and geometric optimization for solar chimney power plants," Solar Energy, vol. 139, pp. 228-237, 2016.

[30] W. Haaf, K. Friedrich, G. Mayr, and J. Schlaich, "Solar chimneys part I: principle and construction of the pilot plant in Manzanares," International Journal of Solar Energy, vol. 2, no. 1, pp. 3-20, 1983.

[31] J. R. Schlaich, R. Bergermann, W. Schiel, and G. Weinrebe, "Design of commercial solar updraft tower systems-utilization of solar induced convective flows for power generation," Journal of Solar Energy Engineering, vol. 127, no. 1, pp. 117$124,2005$.

[32] P. M. Cuce, E. Cuce, and H. Sen, "Improving electricity production in solar chimney power plants with sloping ground design: an extensive CFD research," Journal of Solar Energy Research Updates, vol. 7, no. 1, pp. 122-131, 2020.

[33] E. Cuce, A. Saxena, P. M. Cuce, H. Sen, S. Guo, and K. Sudhakar, Performance Assessment of Solar Chimney Power Plants with the Impacts of Divergent and Convergent Chimney Geometry, International Journal of Low-Carbon Technologies, 2021. 